certificate would be to-day worth $I l$. because the nation will pay $I l$. for it in five years' time. I fear that he stands alone in this valuation.

H. Lovis.

\section{Man's Ancestry.}

IN relation to your reviewer's interesting notice in NATURE for June 27 of Prof. Wood-Jones's booklet, "The Problem of Man's Ancestry," it is appropriate to remember that the "bloodreaction test" shows the relationship of man to the ape to stand exactly as that of the horse to the donkey; the latter have had a common ancestor. Taking man as equalling Ioo, the ape comes at 70 ; the numbers for the horse and the donkey are the same. But this test shows no blood relationship whatever between man and the lower animals, thus confirming Klaatsch's view that the human line became separated very far down at the basis of the vertebrate phylum.

W. Woods Smyth.

Maidstone, July 3 .

THE similarity in the reaction of human and anthropoid blood is the most convincing evidence we have of man's close relationship to the gorilla, chimpanzee, and orang. The classical experiments on blood immunity and blood relationships carried out by Prof. Nuttall, of Cambridge, in the opening years of the present century assured him that those anatomists were right who brought man and anthropoid apes from a common stock. All the biological evidence collected since 1904 has supported Prof. Nuttall's conclusion. When attempts have been made to transmit diseases which are peculiar to man, such as syphilis and typhoid, it has always been found that the great anthropoid apes are more susceptible than any other primate, and much more than any other mammal. When physiologists wish to discover the action of any particular part of the human brain they invariably select an anthropoid ape as the subject most likely to yield the information which is being searched for. But I do not know of any anatomist who has claimed that the relationship between man and the gorilla or between man and the chimpanzee is as close as that which exists between the horse and ass. The structural difference between the gorilla and chimpanzee is greater than that which differentiates the horse from the ass; the structural difference between man and the gorilla is still greater.

It is for those who hold that man has arisen by an independent line from a primitive mammalian stock to explain why man's blood gives no reaction with the blood of lower animals. If it is true that man is a primitive form and retains primitive characters, then we should expect his blood to yield such reactions. The fact that it does not supports the usually accepted hypothesis that man has arisen from an anthropoid stock.

THE Reviewer.

\section{POSITION AND PROSPECTS OF THE HOME TIMBER SUPPLY.}

$\mathrm{HE}$ utility of forests to a nation is one of the economic factors to its well-being which have been brought to an unforeseen prominence during the world-war; and perhaps to no other European nation has this unlooked-for development proved so startling, because so totally unsuspected, as to ourselves.

Our woods were not grown from the commercial aspect--sport, amenity, and shelter to crops and stock were their main raison d'être. We did not NO. 2542 , VOL. IOI] consider it necessary to grow woods for purely commercial reasons - that is, for the sake of the timber and pit wood and paper pulp, etc., they would yield. We obtained our requirements in these commodities by importing them from abroad, and relied on the Navy being able to safeguard these imports. We have now discovered,our mistake and are paying for it. The timber purchased in 1915 and 1916 cost $37,000,000$. more than it would have done in $1909^{-1} 3$.

On the Continent it was thought that the utility of the forest to a nation was thoroughly understood, but a study of Continental text-books discloses the fact that, so far as modern warfare is concerned, even there the value of the forest and its close connection with the operations of the contending armies were but dimly foreseen. It may be on record, perhaps, in the archives. of the German War Office that an exceptionally large demand for timber might prove one of the essential factors to the successful waging of a great war. But it is doubtful whether the Germans even foresaw the magnitude of the demands; and, in any event, they would have calculated on obtaining their requirements in this respect from the countries they overran-as, in fact, has been the case in France, Belgium, Poland, and elsewhere. Nor was it anticipated that the destruction of forests would be so heavy in the fighting zones. In the western provinces of Russia, for instance, from which the Baltic ports were mainly supplied, some $16,000,000$ acres of forest have been destroyed! This in itself will limit the amount we are likely to receive from the Baltic in the future. Destruction and heavy fellings are, then, taking place throughout Europe, and, with our timber imports reduced to a negligible amount, we have now been felling heavily for some time past in our own small area of $3,000,000$ acres of woodlands, of which probably not much more than half will be commercially exploitable. It will be alike useful and of interest to consider briefly the present position and future prospects of this timber question.

Almost from the outbreak of war we have been living a hand-to-mouth existence so far as timber supplies are concerned. The first troubles arose with the pit-wood requirements of the collieries, and the matter has remained a difficult one throughout. Our position as the coal producer and coal merchant of the Allies has rendered it essential to keep the collieries working at full pressure. Previous to the war three-quarters of our pit-wood supplies came from Russia and France; this amount was cut off at a moment's notice with the closure of the Baltic ports and the calling to the colours of the French woodcutters. The price at once rose, and though the imports continued for some time, the increasing demands made upon tonnage for other purposes, coupled with the German submarine campaign, gradually reduced them to a very small figure. We had to fall back upon our home woods for this product. A demand also quickly arose for ash with which to fashion the handles of entrenching tools; but the use of 